\title{
SOIL SEALING AND UNSEALING: STATE OF THE ART AND EXAMPLES
}

Short title: SOIL SEALING AND UNSEALING

Silvia Tobias*a), Franz Conen ${ }^{\text {b), Adrian Duss }}{ }^{\mathrm{a}) c)}$, Leonore M. Wenzelb), Christine

Busera)c), Christine Alewellb)

a)Swiss Federal Research Institute WSL, Landscape Ecology Group, Zürcherstrasse 111, 8903 Birmensdorf, Switzerland, silvia.tobias@wsl.ch

b)University of Basel, Department of Environmental Sciences, Bernoullistrasse 30, 4056

Basel, Switzerland

c)University of Zurich, Department of Geography, Winterthurerstrasse 190, 8057 Zurich, Switzerland

${ }^{*}$ Corresponding author (also for proofs):

Silvia Tobias; silvia.tobias@wsl.ch;

Swiss Federal Research Institute WSL; Zürcherstrasse 111; CH-8903 Birmensdorf,

Switzerland

Tel: +41-44-73923 49; fax: +41-7392215

This article has been accepted for publication and undergone full peer review but has not been through the copyediting, typesetting, pagination and proofreading process which may lead to differences between this version and the Version of Record. Please cite this article as doi: $10.1002 / / d r .2919$ 


\section{Abstract}

Soil sealing for urban and infrastructure development constitutes the most intense form of land degradation and affects all ecosystem services. Researchers and policy makers have become aware of this fact and call for limiting development and compensating for new soil sealing with unsealing measures. In a literature review, we found that the state of research about the impacts of soil sealing is far more advanced than about the potential and prerequisites of unsealing. In practice, soil restoration after mining and construction activities as well as redevelopment or renaturation of abandoned industrial sites are increasingly important issues, but systematic research on the success of soil unsealing and restoration is rare. In particular, the development of soils and vegetation after unsealing and restoration measures as well as their potential to provide ecosystem services need more detailed investigation.

In three case studies, we demonstrate that replacing a sealed surface with soil to restore ecosystem services is always beneficial for humans and nature. An indicator-based mapping approach revealed the potential performance of different ecosystem services at former industrial sites in Switzerland. When unsealed sites are transformed to pioneer habitats, the intended vegetation may successfully be regained, but landscape connectivity is hardly enhanced due to increased overall landscape fragmentation. Our investigations show that with the techniques currently applied, the soil physical parameters in a restored agricultural soil developed favourably for crop growth within 15 years. However, unsealed soils are anthropogenic soils with reduced multifunctionality and protecting natural soil against sealing is always the better option.

\section{Key words}

soil restoration, land recycling, brownfield regeneration, SUITMA, circular flow land use management

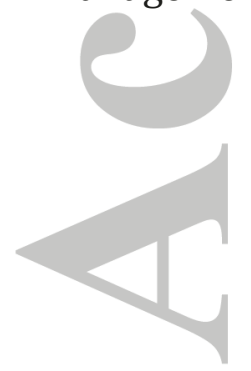




\section{Introduction}

In a world of climate and land use change, soils are essential to sustain life generally and humans in particular (Amundson et al., 2015). In addition to soil erosion, soil sealing (for definition refer to Table 1) is one of the greatest threats to the soil and its ecosystem services (Montanarella, 2007; EC, 2012) and is a common syndrome of land degradation around expanding urban areas. Historically, most cities arose in agriculturally productive regions. Hence, their growth coincides with a degradation of the most fertile land (Ceccarelli et al., 2014). Prokop et al. (2011) estimated that artificial surfaces covered $4.4 \%$ of the total surface area of the 27 member states of the European Union in 2011 (EU 27), of which 51\% was imperviously sealed and amounted to more than $100,000 \mathrm{~km}^{2}$. From 2000 to 2006, the increase in artificial surfaces in EU 27 was $3 \%$, which is greater than the total increase in population of $2 \%$. This development leads to a continuous rise in land-take per capita and year of approx. $2 \mathrm{~m}^{2}$ of additional artificial surface.

Conversely, countries with predominant service economies often have considerable expanses of brownfields (Table 1) because societal and economic changes have led to changing requirements regarding the location of industries and infrastructure, or because military sites have been closed. In 2000, the Netherlands and Belgium, for example, hosted 10,000 and 14,500 hectares, respectively, France 20,000 hectares, England and Scotland 67,000 hectares, and Germany 128,000 hectares of brownfields. The largest extent of brownfield area was reported from Poland with 800,000 hectares and Romania with 900,000 hectares (Oliver et al., 2005).

Sealing greenfields without restoring brownfields is clearly unsustainable, as soils are destroyed and the options of future generations to satisfy their needs are restricted even further. Unsealing brownfields and restoring ecosystem services should increasingly be considered as a contribution to reduce net soil loss and to preserve the overall natural capital for future generations. US EPA (2014) promotes unsealing soils as a contribution to green infrastructure and points out the multiple benefits for humans and nature. However, unsealing soil usually requires the remediation of contaminated sites or at least the insolation of the contaminants, which causes 
additional costs. Yet remediation costs also arise, if contaminated brownfields are regenerated for developed uses such as residential areas.

This paper presents a brief literature review on the state of research and practice considering the impacts of soil sealing and the efforts of soil unsealing. We further present three case studies, in which we assessed the potential and feasibility of restoring ecosystem services by unsealing soil.

\section{Literature review}

\subsection{Method of literature review}

We analysed literature on the state of research on the impacts of soil sealing and the state of the art in soil unsealing. We used the Google search machine because, particularly for soil unsealing, it was comparably more comprehensive (including so called "grey" literature such as reports from authorities or research projects) than the Web-of-Science. We used the key words "land-take" and "soil sealing" in combination with "ecosystem services" to access recent research on the impacts of land-take and soil sealing. To find literature about soil unsealing, we used the key words "soil unsealing/dismantling", "land recycling" and "brownfield regeneration/renaturation" separately. We searched for the key words in the titles, key words and texts of English and German publications. After screening the abstracts, we selected ca. 50 articles on soil sealing and 35 publications on unsealing.

\subsection{Soil sealing: a core reason for land degradation in industrialised countries}

Soil sealing in the course of urban sprawl can be considered an active driver of desertification (Barbero-Sierra et al., 2013), which is the most serious form of land degradation. Soil sealing directly influences the soil's regulating services (Scalenghe \& Ajmone Marsan, 2009; Tobias, 2013). Sealed surfaces prohibit water infiltration and cause stronger surface run-off. Underground soil sealing for basements or garages additionally reduce the water infiltration paths and consequently the soil's water purification capacity (Nakayama et al., 2007). The predominance of heat-absorbing concrete and asphalt together with the absence of evaporating vegetation entail the effect of heat islands in cities (Bolund \& Hunhammar, 1999). The use of sealed areas for 
industry or car traffic additionally affects unsealed soils in the neighbourhood with pollutants (Mendyk \& Charzyński, 2016; Charzyński et al., 2016).

Land-take for urban and infrastructure development has further a strong impact on the soil's provisioning services. The loss of agricultural land due to development is particularly high in countries with strongly growing populations and economies (Toth, 2012). Gardi et al. (2014) estimated a total loss of agricultural land in 21 member states of the EU 27 between 1990 and 2006 of 12,000 km². They further calculated the consequent yield loss for 19 states in their sample being more than six million tonnes of wheat per year.

Considering supporting services, soil sealing strongly reduces the soil's function as natural habitat. As topsoil is usually removed, soil sealing entails a considerable loss in soil biodiversity (Scalenghe \& Ajmone Marsan, 2009; Montanarella, 2007).

Consequently, soil sealing reduces the total and microbial content of carbon and nitrogen and soil respiration (Piotrowska-Dlugosz \& Charzyński, 2015). The remnant natural habitats are often fragmented due to roads and railway-lines. Jaeger et al. (2011) showed for Europe that the greatest landscape fragmentation occurs in densely populated regions with dense transportation systems. Urban expansion and landscape fragmentation lead to a considerable shift in species richness towards generalist and ubiquist species at the expense of specialist and indigenous species (Di Giulio et al., 2009; Concepción et al., 2016).

Even cultural ecosystem services may be impaired by soil sealing, as can be derived from the fact that people are willing to pay higher housing prices at places with views on natural landscape elements or urban parks (Tyrwäinen, 1997; Waltert \& Schläpfer, 2010). In addition, urban parks and undeveloped landscapes are important places for recreation (Frick et al. 2007; Home et al., 2007).

Not only researchers but also policy makers have become aware of the negative consequences of soil sealing and have taken reduction measures. Some countries, e.g. Germany and Austria, set targets of future land-take of max. 30 and 25 hectares per day, respectively. However, these national targets are rather strategic measures and have little impact on the municipalities' planning practices (EC, 2012). More efficient may be the practice of the Czech Republic and Slovakia, which require a fee for development on fertile agricultural land. Measures to reduce soil sealing inside urban areas are also 
promoted such as permeable surfaces on parking lots or tramways. Numerous cities reduce the sewerage fees for landowners, who let rainwater infiltrate on their parcels. The city of Dresden even introduced the duty to unseal brownfields, if greenfield inside the city perimeter should be developed. Although this is the strongest measure to compensate for new land-take, the city did not enforce it because it seemed to intimidate potential investors (Prokop et al., 2011).

\subsection{Soil unsealing: state of the art in research and practice}

Specific research on soil unsealing and brownfield regeneration is scarce. However, some soil scientists have recognized the importance of soils in urban, industrial, traffic, mining, and military areas, so-called SUITMAs (Table 1), for human wellbeing even though these soils often have only a limited potential of delivering ecosystem services (Morel et al., 2015; Charzyński et al., 2013; Séré et al., 2008). The researchers recommend to technically upgrade urban, brownfield or dumping site soils so that they can be reused as urban parks, greenroofs or even for urban gardening provided that the soils were remediated from pollutants.

A European research project promoted a circular flow land use management among planners and municipal authorities (www.circuse.eu), which aims at avoiding development on greenfield areas, at recycling brownfield sites by re-development or renaturation, and at compensating for development on greenfields by renaturation or unsealing measures (Preuss \& Verbücheln, 2013). Another project developed a decision and implementation framework for brownfield regeneration addressing local authorities, landowners and investors with the intention to reduce the number of brownfields to zero (www.zerobrownfields.eu).

Oliver et al. (2005) discovered population density and economic competitiveness as driving factors of a European country's brownfield management strategy. The regeneration and reuse of brownfields has become a key issue in competitive countries with high population densities such as Germany, the UK, Belgium and the Netherlands because greenfield that could be developed is increasingly scarce. Countries with low population density but high economic competitiveness such as the Scandinavian countries and Ireland limit their brownfield management to the remediation of contaminated sites, whereas countries with medium population densities and relatively 
low economic competitiveness such as the Mediterranean and former socialist countries rarely show active brownfield management.

Brownfield regeneration, however, means unsealing a sealed area only in a few cases. The European Environment Agency (EEA, 2016) includes urban densification or infill development in land recycling and further distinguishes between "grey" and "green" land recycling (Table 1). Comparing the proportions of these measures, implemented between 2006 and 2012 in the urban fringes of 23 European capitals, reveals that infill development is mostly implemented to contain land-take on greenfields. In the city regions of Riga, Bucharest and Bratislava, grey recycling, i.e. redevelopment of brownfields, amounted to 60 and $70 \%$ of the land recycling measures implemented. However, only in four capital regions (Stockholm, Copenhagen, Talinn, Bratislava), green recycling measures, i.e. re-creating unsealed areas, amounted to $10 \%$ or more of the total land recycling efforts.

In practice, numerous brownfield sites were converted into urban parks in the United States, Canada (De Sousa, 2003, 2004), the UK (Doick et al., 2006), and Germany (BMVBS/BBR, 2007), what considerably improved the recreational qualities of the neighbourhoods (De Sousa, 2006). Famous examples are the Chicago Millennium Park (Texas A\&M University and DePaul University, 2011), the Emscher Landscape Park in the Ruhr region in Germany or the Thames Barrier Park in London (Villella et al., 2006). Green land recycling is a major issue in shrinking cities in Eastern Germany; by 2007, $85 \%$ of the urban brownfields in cities had been converted into parks or gardens (BMVBS/BBR, 2007). The Scottish Executive (2013) reports that, in the years 2011 and $2012,14 \%$ of the Scottish brownfields had been unsealed and were used for agriculture, forestry, nature conservation or recreation. Moreover, a considerable number of abandoned military sites were incorporated in the EU "Natura 2000" network of natural habitats: examples are in Denmark, the Netherlands and Belgium, where 45\%, 50\% and even $70 \%$ of the former military sites were included, respectively (Gazenbeek, 2005).

As investors usually fear the costs of decontamination, public authorities subsidise brownfield remediation in many cases. In Eastern Germany, for example, municipalities strongly relieve private investors, if they reuse a site that was contaminated before 1990 (EC, 2012). The superfund of the US Environment Protection Agency (EPA) (www.epa.gov/superfund), established in 1980, gave EPA the authority to clean up 
hazardous waste sites. Financial resources for subsidising brownfield remediation can be generated from soil sealing fees, other fees for ecological compensation measures, or levies on added values due to zoning in construction zones (EC, 2012). Municipalities could definitely contribute more to sustainable land management with subsidising brownfield remediation than with financing infrastructure development on greenfields to attract investors.

Unsealed sites are often promoted as beneficial for nature because they offer the chance for pioneer ecosystems to develop (Latkowska, 2014; US EPA, 2014). However, the development of natural habitats on unsealed sites has rarely been systematically investigated. Kovarik \& Langer (2005) assessed the natural succession on an abandoned railyard in Berlin, and Shackelford et al. (2017) analysed a 10-year monitoring of opencast mining restorations in Western Australia. In both studies, a strong development of the woody vegetation was observed. On the abandoned railyard, the area of woods almost doubled within 10 years from $37 \%$ to $70 \%$ of the site's total area, however, at the expense of rare species, which were primarily found in the dry grasslands. On the Australian mining restorations as well, the woody species had developed better compared to natural reference sites than herbaceous species. The deeper roots of woody vegetation can reach water in deeper soil layers, which may be a reason for its successful establishment on such rather dry sites.

The prerequisites for successful restoration of agricultural or forest soils are well known in practice from soil restorations after temporary construction or raw material exploitation. Removing and heaping soil under wet conditions in combination with using heavy construction machinery caused strong soil compaction in the past (Harris et al., 1996). Great progress in soil restoration has been made in the last three decades with improved techniques and machinery, and with stricter control mechanisms. Although the restoration of agricultural and forestland is a big issue in practice, scientific investigations of the success of such restorations are rare (e.g. Friedli et al., 1998; Kaufmann et al., 2009; Krümmelbein \& Raab, 2012).

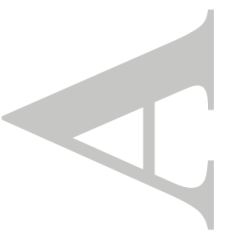




\section{Case studies}

\subsection{Methods of the case studies}

\section{Case study 1: Potential ecosystem service performance at brownfield sites}

We assessed the ecosystem service potentials at 59 industrial brownfields in Switzerland, on which we found information in the national brownfield database (www.brache.areale.ch). We selected the indicators so that all categories of the Common International Classification of Ecosystem Services CICES were represented (Haines-Young and Potschin, 2011), and additionally allowed for transport connections (Table 2). We quantified the indicators with the data available and standardised them on a scoring range from 1 to 5 (cf. Methods S1).

\section{Case study 2: Restoration of regulating and supporting services}

We studied the establishment of natural habitats on a section of a country road that was unsealed to compensate for the construction of a by-pass road (Figure 1). The old road's pavement and gravel foundation had been removed, and a series of wet and dry habitats were created by excavating a ditch connecting two brooks and constructing piles of rocks and wood. Some trees and shrubs were planted and the area was covered with hay from nutrient-poor, high diversity grassland to let its seeds spread naturally.

We investigated the plant communities on the unsealed road section, and assessed two soil profiles on a wet and a dry site, respectively. In addition, we estimated landscape fragmentation before and after the unsealing with the method of the effective mesh size (Bertiller et al., 2007), which indicates the size of coherent areas and can be used as a general indicator of landscape fragmentation.

\section{Case study 3: Restoration of provisioning services}

We followed the development of a Eutric Cambisol that was restored after an opencast tunnel construction in the Swiss Central Plateau. Kaufmann et al. (2009) studied the soil during the first three years after restoration (1999 to 2002). We re-visited the site in 2013 and compared several soil physical parameters with those of an adjacent, 
undisturbed reference site. On both sites, we found sandy loams (Table S3), and land use (crop type, farming practice) had been identical for 10 years. During the first 4 years after restoration, the restored soil was managed very extensively.

We measured bulk density and coarse porosity as indicators of the soil's state of compaction, and precompression stress as an indicator of the soil's susceptibility to compaction. This parameter corresponds to the maximum stress a soil has previously experienced; it can only be further compacted with higher stresses. We conducted a two sample t-test to check the pairwise differences between the measurements on the restored soil from 2002 and 2013, and between the data of 2013 from the restored and the reference soil.

For details on the methods of the case studies, refer to Methods S1, Duss (2014), Buser (2014), and Wenzel (2014).

\subsection{Results of the case studies}

\section{Case study 1: Potential ecosystem service performance at brownfield sites}

Any unsealing of the investigated brownfields would provide some ecosystem service benefits, taking into account the locations and the specific natural and anthropogenic conditions prevailing. Examples are given in Figure 2.

If all brownfields at locations with high potential for agricultural land use were restored for agriculture, 644 hectares of agricultural land could be restored. This area amounts to $78 \%$ of the total brownfield area investigated and corresponds to the management area of ca. 32 Swiss farms with an average management area of 20 hectares. However, Switzerland lost 56900 hectares of agricultural land to residential areas between 1985 and 2009, whereas only 4600 hectares of former residential land were unsealed to farmland (BfS, 2015). In view of these figures, the gain of agricultural land from brownfield unsealing may appear very limited. However, at the moment a considerable area of sealed and degraded soil is left to future generations.

As brownfields are often located in urban regions, conflicts are likely to occur between developed and more natural reuses of brownfields. Half of the brownfields (29 of 59) in Figure 2 have good motorway access, and one third of them are also easily accessible by public transport. Two-thirds of the easily accessible brownfield sites (19) have great 
potential for agricultural production, so that developed and agricultural reuse compete. A similar rivalry arises regarding the reuse of 10 easily accessible brownfield sites as natural habitats, i.e. in $17 \%$ of all cases. In urban regions $(12 \%$ of all brownfields investigated), the marked demand for recreational areas competes with good accessibility for industrial use and to some extent with a high potential for agriculture.

\section{Case study 2: Restoration of regulating and supporting services}

Thirteen years after unsealing the road section (Figure 1), we found typical species of the intended Central European semi-xeric grassland (Mesobromium erecti) (Table S1). The plant community had become well established in terms of species abundance and distribution (Table S2). We found six red list plant species in the unsealed road section (Table S1), but nutrient-poor grassland could potentially host considerably more. As the surrounding area is mostly intensively used for agriculture, probably very few rare species were able to migrate into the unsealed site. The succession of woody vegetation has been much slower than in the examples of Kowarik \& Langer (2005) and Shackelford et al. (2017; cf. section 2.3) because the soil had been compacted to form the foundation for the former country road.

The soil profiles show a very shallow A horizon, immediately followed by a deep C horizon (Figure 3) of fine-grained sandy loam, which is heavily compacted. The soil is now a Regosol (Densic) (IUSS Working Group WRB, 2015). It is fed by rainwater only and can only host plants with shallow roots that simultaneously tolerate standing water and thrive on dry soils. In addition, the compaction restricts the soil's water regulation services, as it impedes water infiltration to groundwater aquifers.

If every small road is considered as a fragmenting element, the approximate perimeter of Figure 1 was far more fragmented in 2002 after unsealing than it was in 1980 (Table S6). In 1980 the average size of coherent areas was $1.29 \mathrm{~km}^{2}$, which is ten times larger than in $2002\left(0.12 \mathrm{~km}^{2}\right)$. If only railways, motorways and main roads are considered, the average size of coherent areas in the perimeter decreased by approx. $10 \%$ from 2.67 $\mathrm{km}^{2}$ to $2.41 \mathrm{~km}^{2}$. This is, however, not a failure of the road unsealing but a consequence of the general process of urban and infrastructure development. The unsealed road 
section actually is now a new piece of green infrastructure connecting a forest with a restored creek and a wetland (Figure 1).

\section{Case study 3: Restoration of provisioning services}

Our results indicate that the restored subsoil had consolidated and assimilated to the reference subsoil. The measured values of the restored subsoil had changed significantly from 2002 to 2013, and there was no significant difference between the restored and reference subsoils in 2013 (Table 3).

Conversely, the topsoil measurements show significant differences between the restored and the reference soil, but not between the two points in time when the restored topsoil was investigated. Although the farmer applied the same management practices, the restored topsoil remained less compacted than the reference soil. Overall, our results indicate the technical feasibility of restoring soils for agriculture after excavation and storage on heaps.

\section{Conclusions}

Urban growth usually affects the most productive agricultural land and is a core driver of land degradation in industrialised countries. Sealing soil with an impervious surface destroys all ecosystem services, whereas technically restored soils can provide essential ecosystem services, as research on soils in urban environments (SUITMAs; Table 1) has shown. Soil restoration and brownfield renaturation is increasingly implemented in practice, but research in these fields is scarce compared to research on the effects of soil sealing.

Our case studies show that every brownfield site we investigated has a considerable potential to deliver ecosystem services, if it was unsealed and the soil restored. The case studies further confirm that it is technically feasible to restore agricultural soils and natural habitats for pioneer ecosystems, but subsoil compaction often limits soil multifunctionality. Moreover, unsealing measures need to be done to a much larger extent to enhance landscape connectivity in densely developed regions because of the 
existing strong overall fragmentation. Our results indicate that the performance of ecosystem services after soil unsealing depends on the soil conditions at the specific locations, and more research on the development of unsealed soils is necessary to assess the potential and limitations in restoring ecosystem services.

\section{Acknowledgements}

We thank Peter Weisskopf and Marlies Sommer from Agroscope Reckenholz for their generous support with the soil analyses. We further thank Silvia Dingwall for editing the English and Andri Baltensweiler from WSL for the GIS work for Figure 1. Finally, we acknowledge the valuable remarks of the anonymous reviewers of previous versions of the manuscript.

\section{Supporting information}

The online version of this article includes detailed information about the research methods and the results of the case studies:

Methods S1 describes the research procedures;

Table S1 presents an excerpt of the list of plant species found on the unsealed road section;

Table S2 is a comparison of our own measurements of Shannon and Evenness indices at the unsealed road section we studied with those in the literature;

Table S3 shows the soil texture of the soil at the unsealed road section;

Table $S 4$ gives the results of the landscape fragmentation assessment around the unsealed road section;

Table S5 shows the soil texture of the restored and the reference soils we investigated (agricultural soil).

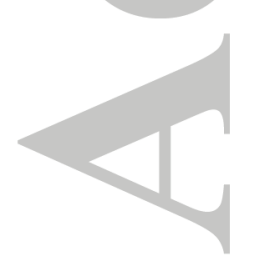




\section{References}

Amundson R, Berhe AA, Hopmans JW, Olson C, Sztein AE, Sparks DL. 2015. Soil and human security in the 21st century. Science 348: 647-653. DOI: $10.1126 /$ science. 1261071

Barbero-Sierra C, Marques MJ, Ruiz-Pérez M. 2013. The case of urban sprawl in Spain as an active and irreversible driving force for desertification. Journal of Arid Environments 90, 95-102. DOI: 10.1016/j.jaridenv.2012.10.014

Bertiller R, Schwick C, Jaeger JAG. 2007. Landschaftszerschneidung Schweiz. Zerschneidungsanalyse 1885-2002 und Folgerungen für die Verkehrs- und Raumplanung. ASTRA-Bericht, Bern. 142 pp.

BfS Bundesamt für Statistik. 2015. Die Bodennutzung in der Schweiz. Auswertungen und Analysen. Neuchâtel, 64 pp.

BMVBS/BBR Bundesministerium für Verkehr, Bau und Stadtentwicklung / Bundesamt für Bauwesen und Raumordnung (eds.), 2007. 5 Jahre Stadtumbau Ost - eine Zwischenbilanz. Zweiter Statusbericht der Bundestransferstelle. Berlin, 113 pp.

Bolund P, Hunhammer S. 1999. Ecosystem services in urban areas. Ecological Economics 29: 293-301. PII: S0921-8009(99)00013-0

Buchecker M, Kienast F, Degenhardt B, Widmer S, Moritzi M. 2013. Naherholung räumlich erfassen. WSL Merkblatt für die Praxis 51: 8 pp.

Buser C. 2014. Ökologische Entwicklung von versiegelten Flächen am Beispiel von Hettlingen (ZH). Master thesis University of Zurich. Department of Geography. 71 pp.

Ceccarelli T, Bajocco S, Salvati L, Perini L. 2014. Investigating syndromes of agricultural land degradation through past trajectories and future scenarios. Soil Science and Plant Nutrition 60: 60-70. DOI:10.1080/00380768.2013.843438

Charzyński P, Hulisz P, Bednarek R. 2013. Technogenic soils of Poland. Polish Society of Soil Science, Torun ISBN 978-83-934096-1-7, 358 pp.

Charzyński P, Plak A, Hanaka A. 2016. Influence of the soil sealing on the geoaccumulation index of heavy metals and various pollution factors. Environmental Science and Pollution Research 24: 4801-4811. DOI:10.1007/s11356-016-8209-5.

Concepción E, Obrist MK, Moretti M, Altermatt F, Baur B, Nobis MP. 2016. Impacts of urban sprawl on species richness of plants, butterflies, gastropods and birds: not only built-up area matters. Urban Ecosystems 19: 225-242. DOI: 10.1007/s11252015-0474-4

De Sousa CA. 2003. Turning brownfields into green space in the City of Toronto. Landscape and Urban Planning 62: 181-198. PII: S0169-2046(02)00149-4

De Sousa CA. 2004. The greening of brownfields in American cities. J. Environmental Planning and Management 47: 579-600. DOI: 10.1080/0964056042000243249

De Sousa CA. 2006. Unearthing the benefits of brownfield to green space projects: an examination of project use and quality of life impacts. Local Environment: International J. of Justice and Sustainability, 11: 577-600. DOI: $10.1080 / 13549830600853510$

This article is protected by copyright. All rights reserved. 
Di Giulio, M., Holderegger, R., Tobias, S., 2009. Effects of habitat und landscape fragmentation on humans und biodiversity in densely populated landscapes, J. of Environmental Management 90: 2959-2968. DOI:10.1016/j.jenvman.2009.05.002

Doick KJ, Sellers G, Hutchings TR, Moffat AJ. 2006. Brownfield sites turned green: realising sustainability in urban revival. In: Brebbia CA, Mander U. (eds.): Brownfields III. Prevention, assessment, rehabilitation and development of brownfield sites. Southampton: WIT Press:131-172. DOI: 10.2495/BF060131

Duss A. 2014. Brachflächenrückbau in der Schweiz. Master thesis University of Zurich. Department of Geography. 189 pp.

EC. 2012. Commission Staff Working Document, 'Guidelines on best practice to limit, mitigate or compensate soil sealing'. Downloaded on April 19, 2017: http://ec.europa.eu/environment/soil/ pdf/guidelines/EN\%20\%20Sealing\%20Guidelines.pdf

EEA, European Environment Agency. 2016. Land recycling in Europe. EEA Report 31, 51 pp.

FOEN Federal Office of Environment. 2012. Natural hazards. Aquaprotect. Downloaded on Dez. 18, 2013:

http://www.bafu.admin.ch/naturgefahren/01916/06598/index.html?lang=en

Frick J, Degenhardt B, Buchecker M. 2007. Predicting local residents' use of nearby outdoor recreation areas through quality perceptions and recreational expectations. For. Snow Lands. Res. 81: 31-41.

Friedli B, Tobias S, Fritsch M. 1998. Quality assessment of restored soils: combination of classical soil science methods with ground penetrating radar and near infrared aerial photography? Soil and Tillage Research 46: 103-115. PII S01671987(97)00082-2

Gardi C, Panagos P, Van Liedekerke M, Bosco C, De Brogniez D. 2014. Land-take and food security: assessment of land-take on the agricultural production in Europe. J. Environmental Planning and Management 58: 898-912. DOI: 10.1080/09640568.2014.899490

Gazenbeek A. 2005. LIFE, Natura 2000 and the military. Office for Official Publications of the European Comunities, Luxembourg, 80 pp.

Harris JA, Birch P, Palmer J. 1996. Land Restoration and Reclamation: Principles and Practice. Singapore: Addison Wesley Longman Ltd.: 230 pp.

Haines-Young R, Potschin M. 2011. Common international classification of ecosystem goods and services (CICES): 2011 update. European Environment Agency. Discussion paper for the expert meeting in Dec. 2011: 14 pp.

Home R, Bauer N, Hunziker M. 2007. Constructing Urban Green Spaces: An Application of Kelly's Repertory Grid. Tourism Review 62: 47-52. DOI: 10.1108/16605370780000321

IUSS Working Group WRB. 2015. World Reference Base for Soil Resources 2014, update 2015 International soil classification system for naming soils and creating legends for soil maps. World Soil Resources Reports No. 106. FAO, Rome: 193 pp.

Jaeger JAG, Soukup T, Madriñán LF, Schwick C, Kienast F. 2011. Landscape 
fragmentation in Europe. Joint report of the European Environment Agency EEA and the Swiss Federal Office for Environment FOEN. EEA Report 2/2011: 87 pp.

Kaufmann M, Tobias S, Schulin R. 2009. Development of the mechanical stability of a restored soil during the first 3 years of re-cultivation. Soil and Tillage Research 103: 127-136. DOI:10.1016/j.still.2008.10.002

Kienast F, Degenhardt B, Weilenmann B, Wäger Y, Buchecker M. 2012. GIS-assisted mapping of landscape suitability for nearby recreation. Landscape and Urban Planning 105: 385-399. DOI:10.1016/j.landurbplan.2012.01.015

Kienast F, Frick J, Steiger U. 2013. Neue Ansätze zur Erfassung der Landschaftsqualität. Zwischenbericht Landschaftsbeobachtung Schweiz (LABES). Umwelt-Wissen 1325: $75 \mathrm{pp}$.

Kowarik I, Langer A, 2005. Natur-Park Sudgelande: Linking conservation and recreation in an abondoned railyars in Berlin. In: Kowarik I, Körner S (eds.). 2005. Wild Urban Woodlands. Berlin-Heidelberg: Springer: 287-299.

Krümmelbein J, Raab T. 2012. Development soil physical parameters in agricultural reclamation after brown coal mining with the first four years. Soil and Tillage Research 125: 109-115. DOI: 10.1016/j.still.2012.06.013

Latkowska MJ. 2014. Post-industrial parks: places of protection and revitalisation of industrial areas. Technical transactions architecture 6A: 205-218. Downloaded on March 17, 2017: http://suw.biblos.pk.edu.pl/resourceDetailsRPK\&rId=46594

Mendyk L, Charzyński P. 2016. Soil sealing degree as factor influencing urban soil contamination with polycyclic aromatic hydrocarbons (PAHs). Soil Science Annual 67: 17-23. DOI: $10.1515 /$ ssa-2016-0003

MeteoSchweiz. 2013. Gitterdaten. RhiresD. Downloaded on Jan. 27, 2014: http://www.meteoschweiz.admin.ch/web/de/services/datenportal/gitterdaten/ precip/rhiresd.html

Montanarella L. 2007. Trends in land degradation in Europe. In: Sivakumar MVK. Ndiag'ui N. (eds.). 2007. Climate and land degradation. Berlin, Heidelberg: Springer: 83-104.

Morel JL, Chenu C, Lorenz K. 2015. Ecosystem services provided by soils of urban, industrial, traffic, mining, and military areas (SUITMAs). J Soils Sediments 15: 1659-1666. DOI: 10.1007/s11368-014-0926-0

Nakayama T, Watanabe M, Kazunori T, Morioka T. 2007. Effect of underground urban structures on eutrophic coastal environments. Science of Total Environment 373: 270-288. DOI: 10.1016/j.scitotenv.2006.11.033

Oliver L, Ferber U, Grimski D, Nathanail P. 2005. The scale and nature of European brownfields. CABERNET Working Paper, 8 pp. Downloaded on March 23, 2015 : www.cabernet.org.uk

Piotrowska-Dlugosz A. Charzyński P. 2015. The impact of soil sealing degree on microbial biomass, enzymatic activity, and physiochemical properties in the Ekranic Technosols of Toruń (Poland). J Soils Sediments 15: 47-59. DOI: 10.1007/s11368-014-0963-8 
Preuss T, Verbücheln M (eds). 2013. Toward circular flow land use management. The CircUse Compendium, Berlin. 80 pp.

Prokop G, Jobstmann H, Schönbauer A. 2011. Overview of best practices for limiting soil sealing or mitigating its effects in EU-27. European Communities. 227 pp.

Scalenghe R, Ajmone Marsan F. 2009. The anthropogenic sealing of soils in urban areas. Landscape and Urban Planning 90: 1-10. DOI: 10.1016/j.landurbplan.2008.10.011

Scottish Executive. 2013. Scottish vacant and derelict land survey 2012. Statistical Bulletin. Planning Series PLG/2013/1. Downloaded on November 4, 2013: http://www.scotland.gov.uk/Publications/2013/01/2295.

Séré G, Schwartz C, Ouvrard S, Sauvage C, Renat JC, Morel JL. 2008. Soil construction: a step for ecological reclamation of derelict lands. J Soils Sediments 8: 130-136. DOI: 10.1065/jss2008.03.277

Shackelford N, Miller BP, Erickson TE. 2017. Restoration of open-cut mining in semiarid systems: a synthesis of long-term monitoring data and implications for management. Land Degrad Develop DOI: 10.1002/ldr.2746

Texas A\&M University, DePaul University. 2011. Millennium park. Quadruple net value report. 77 pp. Downloaded on October 13, 2017:

https://www.worldurbanparks.org/en/programs/parks-of-the-world/323-parksof-the-world-millennium-park-chicago-usa

Tobias S. 2013. Preserving ecosystem services in urban regions: challenges for planning and best practice examples from Switzerland. Integrated Environmental Assessment and Management 9/2: 243-251. DOI: 10.1002/ieam.1392

Toth G. 2012. Impact of land-take on the land resource base for crop production in the European Union. Science of the Total Environment 435/436: 202-214. DOI: 10.1016/j.scitotenv.2012.06.103

Tyrväinen, L., 1997, The amenity value of the urban forest: an application of the hedonic pricing method, Landscape and Urban Planning 37: 211-222. PII: S0l692046(96)00354-4

US EPA US Environmental Protection Agency (ed.). 2014. Green infrastructure: land revitalization success stories. EPA 560-F-14-209, Washington DC. 32 pp.

Villella J, Sellers G, Moffat AJ, Hutchings TR. 2006. From contaminated site to premier urban greenspace. Investigating the success of Thames Barrier Park, London. In: Brebbia CA, Mander U, (Eds.). Brownfields III. Prevention, Assessment, Rehabilitation and Development of Brownfield Sites. Southampton: WIT Press: 153-162.

Waltert F, Schläpfer F. 2010. Landscape amenities and local development: a review of migration, regional economic and hedonic pricing studies. Ecological Economics 70: 141-152. DOI:10.1016/j.ecolecon.2010.09.031

Wenzel LM. 2014. Development of restored soils in Switzerland. Master thesis University of Basel. Faculty of Natural Science. 123 pp. 
Table 1 Glossary for the use of particular terms in this paper (own definitions unless references are given)

\begin{tabular}{|c|c|}
\hline Brownfield & $\begin{array}{l}\text { Derelict and underused industrial, commercial or military site, often with real or } \\
\text { perceived soil contamination (EEA, 2016), including unnecessary road and railroad } \\
\text { sections where bypass connections have taken over their functions }\end{array}$ \\
\hline Greenfield & $\begin{array}{l}\text { Undeveloped area used for agriculture, forestry or as natural habitat; usually } \\
\text { located in (semi-) rural regions and often considered as sites for expanding urban } \\
\text { development (EEA, 2016) }\end{array}$ \\
\hline Developed uses & $\begin{array}{l}\text { Land uses requiring the construction of buildings or infrastructure facilities, e.g. } \\
\text { residential or industrial uses, or transportation of people, goods or energy }\end{array}$ \\
\hline Undeveloped uses & $\begin{array}{l}\text { Land uses on soils without artificial surface; e.g. agriculture, forestry, natural } \\
\text { habitats }\end{array}$ \\
\hline Land-take & $\begin{array}{l}\text { Converting agricultural or forestland or natural habitats to residential, industrial, } \\
\text { commercial, or infrastructure areas }\end{array}$ \\
\hline Land & $\begin{array}{l}\text { Converting former industrial, residential, infrastructure land to new land uses; } \\
\text { "grey" land recycling = regenerating brownfields for developed uses; "green" land } \\
\text { recycling = unsealing former brownfields for the reuse as urban parks or for } \\
\text { agriculture or forestry (EEA, 2016) }\end{array}$ \\
\hline Soil sealing & Covering the soil with an artificial impervious surface \\
\hline Soil unsealing & $\begin{array}{l}\text { Removing the artificial surface and converting the area to a new (mostly) } \\
\text { undeveloped land use; this may result in a bare soil for pioneer species, or an } \\
\text { urban park, or a restored soil for agriculture and forestry }\end{array}$ \\
\hline Soil restoration & $\begin{array}{l}\text { Re-establishing soil with the necessary horizons and depth for agriculture or } \\
\text { forestry }\end{array}$ \\
\hline SUITMA & $\begin{array}{l}\text { Soils of Urban, Industrial, Traffic, Mining and military Areas including various soil } \\
\text { types on areas with strong human influence; SUITMA categories: i) pseudo-natural } \\
\text { soils; ii) vegetated engineered soils; iii) dumping site soils; iv) sealed soils (Morel et } \\
\text { al., 2015) }\end{array}$ \\
\hline
\end{tabular}


Table 2 Indicators used for analysing the potential performance of ecosystem services at Swiss brownfields

\begin{tabular}{|c|c|c|c|c|}
\hline $\begin{array}{c}\text { CICES } \\
\text { category }\end{array}$ & Service & Criterion & Indicator & Data source \\
\hline \multirow{4}{*}{$\begin{array}{l}0 \\
0 \\
0 \\
0 \\
0 \\
00 \\
0 \\
0 \\
0 \\
0 \\
0 \\
0 \\
0 \\
0 \\
0\end{array}$} & \multirow{4}{*}{ 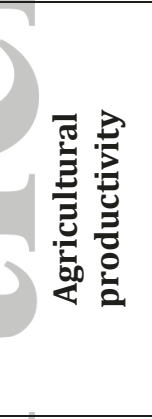 } & Climatic suitability & Climatic suitability & $\begin{array}{l}\text { Swiss map of climatic suitability for } \\
\text { agriculture }(1: 200.000)\end{array}$ \\
\hline & & Soil suitability & Potential crop diversity & $\begin{array}{l}\text { Swiss map of soil suitability for } \\
\text { agriculture }(1: 200.000)\end{array}$ \\
\hline & & \multirow[b]{2}{*}{$\begin{array}{l}\text { Management } \\
\text { suitability }\end{array}$} & $\begin{array}{l}\text { Shape factor = circumference / } \\
\text { area }\end{array}$ & $\begin{array}{l}\text { Calculated with ArcGIS field calculator } \\
\text { and calculate geometry }\end{array}$ \\
\hline & & & $\begin{array}{l}\text { Size of agricultural areas in the } \\
\text { neighbourhood }\end{array}$ & $\begin{array}{l}\text { Own calculations: percentage of points } \\
\text { with agricultural land use in a } 500 \mathrm{~m} \\
\text { buffer (data: Swiss land cover statistics } \\
2004 / 09 \text { ) }\end{array}$ \\
\hline \multirow{7}{*}{ 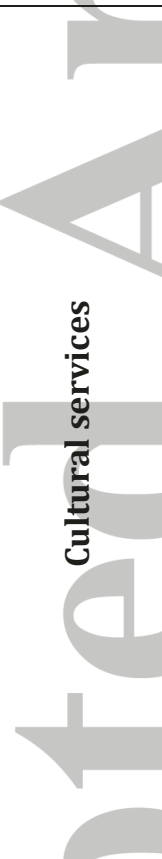 } & \multirow{3}{*}{ 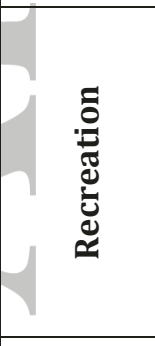 } & $\begin{array}{l}\text { Landscape } \\
\text { suitability for } \\
\text { nearby recreation }\end{array}$ & $\begin{array}{l}\text { Scores representing the } \\
\text { occurrence of landscape } \\
\text { features favouring nearby } \\
\text { recreation }\end{array}$ & $\begin{array}{l}\text { Spatial model of nearby recreation } \\
\text { suitability by Kienast et al. (2012) and } \\
\text { Buchecker et al. (2013) }\end{array}$ \\
\hline & & Potential demand & $\begin{array}{l}\text { Number of residents in a buffer } \\
\text { of } 1 \mathrm{~km}\end{array}$ & Census data 2011 \\
\hline & & $\begin{array}{l}\text { Current green } \\
\text { spaces }\end{array}$ & $\begin{array}{l}\text { Percentage of sealed area } \\
\text { within a buffer of } 1 \mathrm{~km}\end{array}$ & $\begin{array}{l}\text { EEA data base of imperviousness (raster } \\
20 \mathrm{~m} \times 20 \mathrm{~m} \text { ) }\end{array}$ \\
\hline & \multirow{2}{*}{10} & $\begin{array}{l}\text { Topographic } \\
\text { prominence }\end{array}$ & Size of brownfield area & Digitised from orthoimages \\
\hline & & $\begin{array}{l}\text { Touristic potential } \\
\text { of the region }\end{array}$ & $\begin{array}{l}\text { Score of touristic potential } \\
\text { within a buffer of } 1 \mathrm{~km}\end{array}$ & $\begin{array}{l}\text { Model of nearby recreation potential } \\
\text { extended with touristic feature (ski lifts, } \\
\text { restaurants etc.); unpublished }\end{array}$ \\
\hline & \multirow{2}{*}{ 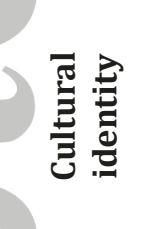 } & $\begin{array}{l}\text { Topographic } \\
\text { prominence }\end{array}$ & Size of brownfield area & Digitised from orthoimages \\
\hline & & $\begin{array}{l}\text { Perceived beauty } \\
\text { of the landscape in } \\
\text { the region }\end{array}$ & Score of landscape aesthetics & $\begin{array}{l}\text { Indicator } 24 \text { of the Swiss landscape } \\
\text { monitoring system LABES (Kienast et } \\
\text { al., 2013) }\end{array}$ \\
\hline \multirow{5}{*}{ 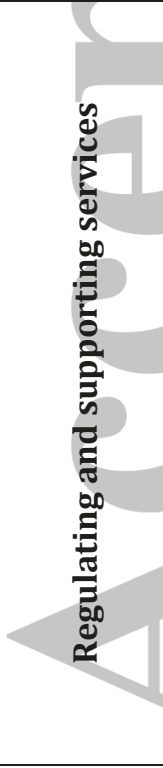 } & \multirow{2}{*}{ 㐫 } & $\begin{array}{l}\text { Degree of } \\
\text { potential natural } \\
\text { infiltration }\end{array}$ & $\begin{array}{l}\text { Degree of imperviousness in a } \\
160 \mathrm{~m} \text { raster grid }\end{array}$ & $\begin{array}{l}\text { EEA data base of imperviousness } \\
\text { (aggregated raster } 160 \mathrm{~m} \times 160 \mathrm{~m} \text { ) }\end{array}$ \\
\hline & & $\begin{array}{l}\text { Regime of strong } \\
\text { rainfall events in } \\
\text { the region }\end{array}$ & $\begin{array}{l}\text { Size of a 2-yearly rainfall event } \\
\text { at the brownfield area }\end{array}$ & $\begin{array}{l}\text { Precipitation data from RhiresD } \\
\text { database (raster } 2 \mathrm{~km} \times 2 \mathrm{~km} \text { ) } \\
\text { (MeteoSchweiz, 2013) }\end{array}$ \\
\hline & 党 & $\begin{array}{l}\text { Suitability of the } \\
\text { brownfield as } \\
\text { flood retention } \\
\text { area }\end{array}$ & $\begin{array}{l}\text { Flood recurrence interval at the } \\
\text { brownfield site }\end{array}$ & Pixel maps Aquaprotect (FOEN, 2012) \\
\hline & \multirow{2}{*}{ 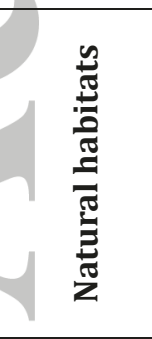 } & $\begin{array}{l}\text { Distances from } \\
\text { potential habitats }\end{array}$ & $\begin{array}{l}\text { Nearest distances from habitats } \\
\text { in national inventories }\end{array}$ & $\begin{array}{l}\text { National inventories of amphibian } \\
\text { spawn territories, water meadows, dry } \\
\text { grasslands, hunting ban territories, } \\
\text { wetlands, migrant bird sanctuaries, and } \\
\text { wildlife corridors }\end{array}$ \\
\hline & & $\begin{array}{l}\text { Landscape } \\
\text { connectivity }\end{array}$ & $\begin{array}{l}\text { Effective mesh size in the } \\
\text { brownfield district }\end{array}$ & $\begin{array}{l}\text { Swiss wide database of effective mesh- } \\
\text { size with a resolution of political } \\
\text { districts (Bertiller et al., 2007) }\end{array}$ \\
\hline
\end{tabular}




\begin{tabular}{|l|l|l|l|l|}
\hline \multirow{2}{*}{} & \multirow{2}{*}{\begin{tabular}{l} 
Public transport \\
\cline { 2 - 4 }
\end{tabular}} & $\begin{array}{l}\text { Motorway } \\
\text { connection }\end{array}$ & $\begin{array}{l}\text { Road length to nearest } \\
\text { motorway connection }\end{array}$ & $\begin{array}{l}\text { Swiss classification of public transport } \\
\text { density for 2013/14 (Web-GIS ARE) }\end{array}$ \\
\cline { 2 - 4 } & facility & Network analysis with ArcGIS closest \\
\hline
\end{tabular}
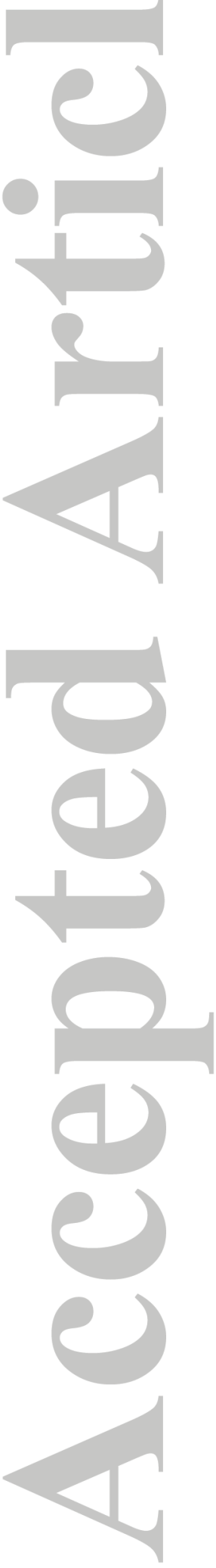

This article is protected by copyright. All rights reserved. 
Table 3 Soil physical parameters of a restored and a reference agricultural soil. Stars indicate significant differences (two sample t-test) between the measurements of the restored subsoil in 2002 and 2013, and between the measurements of the restored and the reference topsoils in 2013: ${ }^{* *} \mathrm{P}=0.05$; *** $\mathrm{P}=$ 0.01. Data sources: Kaufmann et al., 2009 (data 2002; 12 replicates each); own measurements (data 2013; 4-8 replicates each)

\begin{tabular}{|c|c|c|c|}
\hline Bulk density $\left(\mathrm{g} / \mathrm{cm}^{3}\right)$ & \multicolumn{2}{|c|}{ Restored soil } & Reference soil \\
\hline 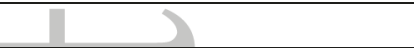 & 2002 & 2013 & 2013 \\
\hline Topsoil $(10-20 \mathrm{~cm})$ & $1.41 \pm 0.094$ & $1.40 \pm 0.043^{* *}$ & $1.31 \pm 0.075^{* *}$ \\
\hline Subsoil $(40-50 \mathrm{~cm})$ & $1.58 \pm 0.046^{* *}$ & $1.52 \pm 0.034^{* *}$ & $1.56 \pm 0.052$ \\
\hline \multicolumn{4}{|l|}{ 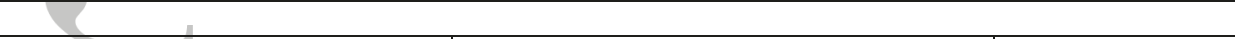 } \\
\hline Coarse porosity (\%) & \multicolumn{2}{|c|}{ Restored soil } & Reference soil \\
\hline$T$ & 2002 & 2013 & 2013 \\
\hline Topsoil $(10-20 \mathrm{~cm})$ & $12.6 \pm 2.81$ & $13.9 \pm 2.51 * *$ & $9.9 \pm 2.35 * *$ \\
\hline Subsoil $(40-50 \mathrm{~cm})$ & $8.8 \pm 2.73 * *$ & $11.7 \pm 1.06 * *$ & $9.6 \pm 3.07$ \\
\hline \multicolumn{4}{|l|}{$>$} \\
\hline Precompression stress ( $\mathrm{kPa}$ ) & \multicolumn{2}{|c|}{ Restored soil } & Reference soil \\
\hline r & 2002 & 2013 & 2013 \\
\hline Topsoil $(10-20 \mathrm{~cm})$ & $36.9 \pm 13.03$ & $50.7 \pm 19.28^{* * *}$ & $82.7 \pm 14.86 * * *$ \\
\hline Subsoil $(40-50 \mathrm{~cm})$ & $41.8 \pm 12.03 * * *$ & $70.0 \pm 38.73 * * *$ & $125.4 \pm 32.95$ \\
\hline
\end{tabular}




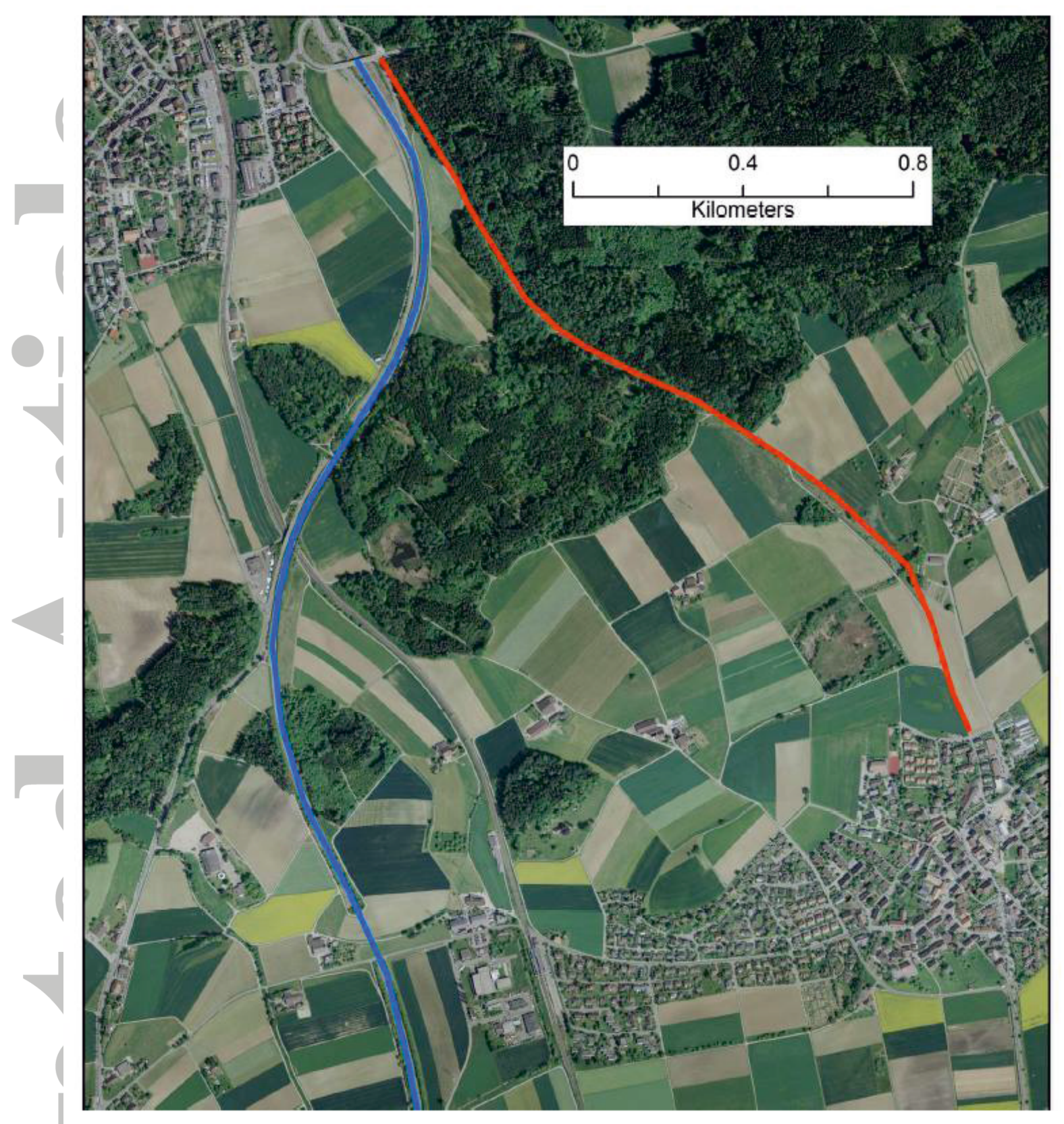

Figure 1 A $2 \mathrm{~km}$ section of an old country road was unsealed in 1996 and converted to natural habitats (red line) to compensate for a new $4 \mathrm{~km}$ long section of a bypass motorway (blue line). (Orthoimage: Swisstopo) 


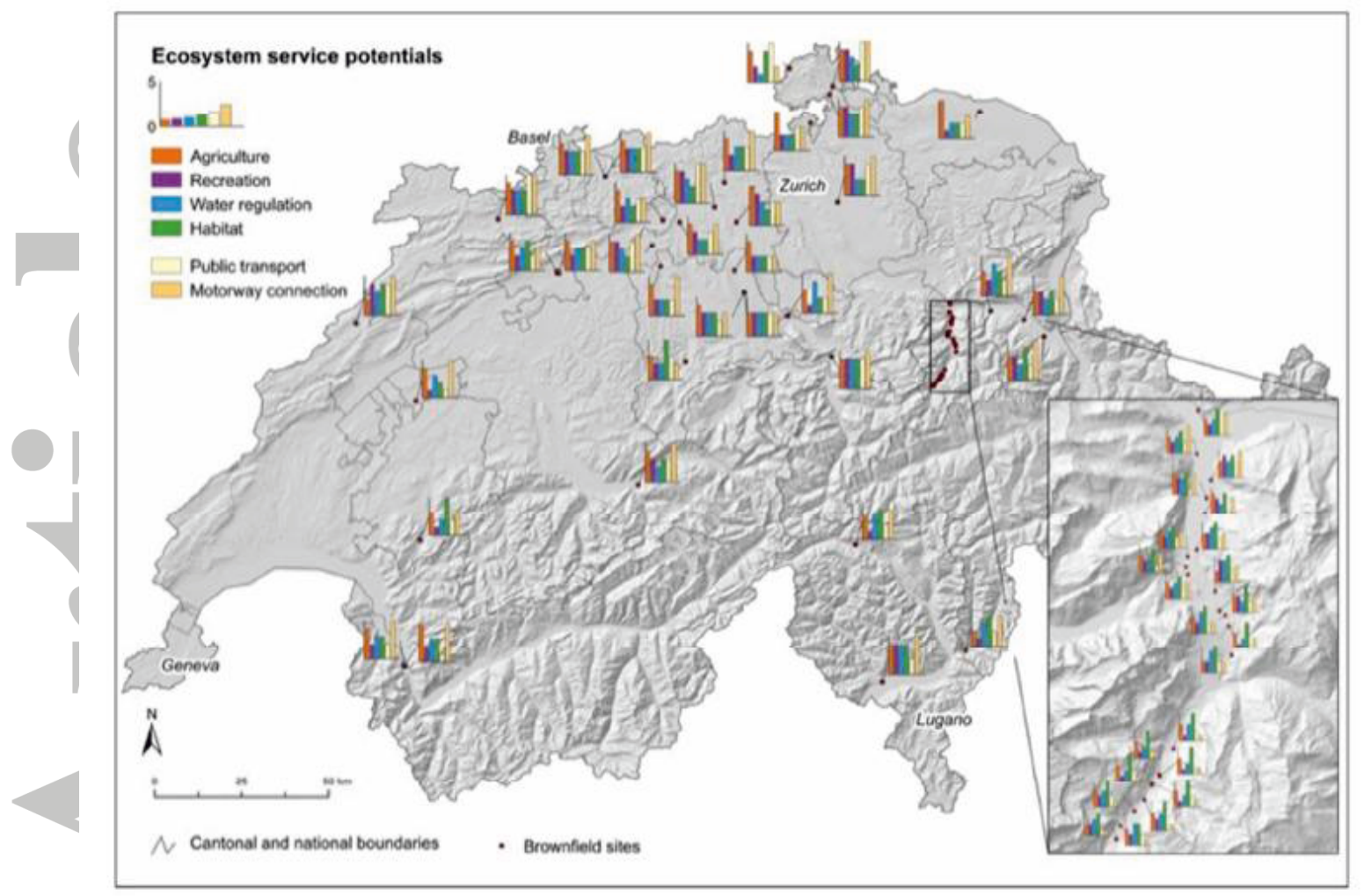

Figure 2 Spatial distribution of 59 brownfields in Switzerland (red dots) and the potential performance of different ecosystem services if these brownfield areas were unsealed. (Background map: DHM25 L2 (C) swisstopo (5704 000 000) / BFS GEOSTAT / Bundesamt für Landestopographie)

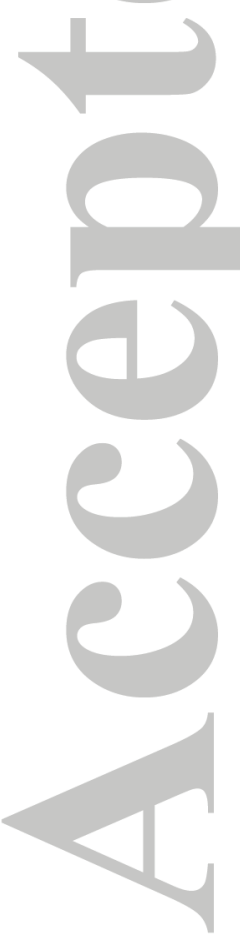




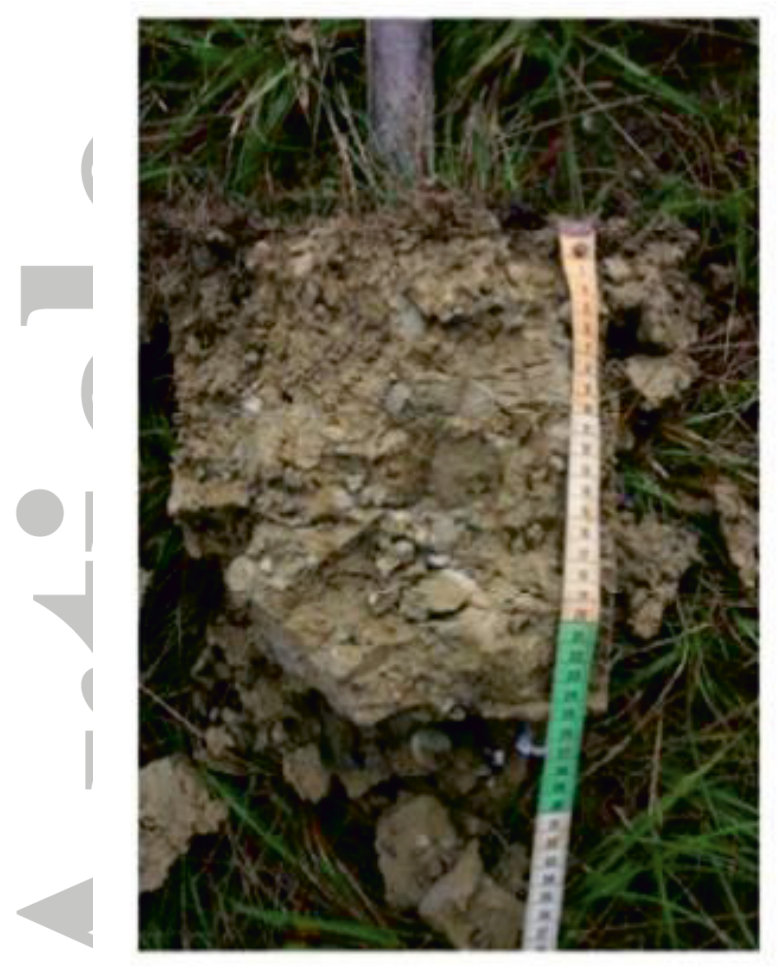

a)

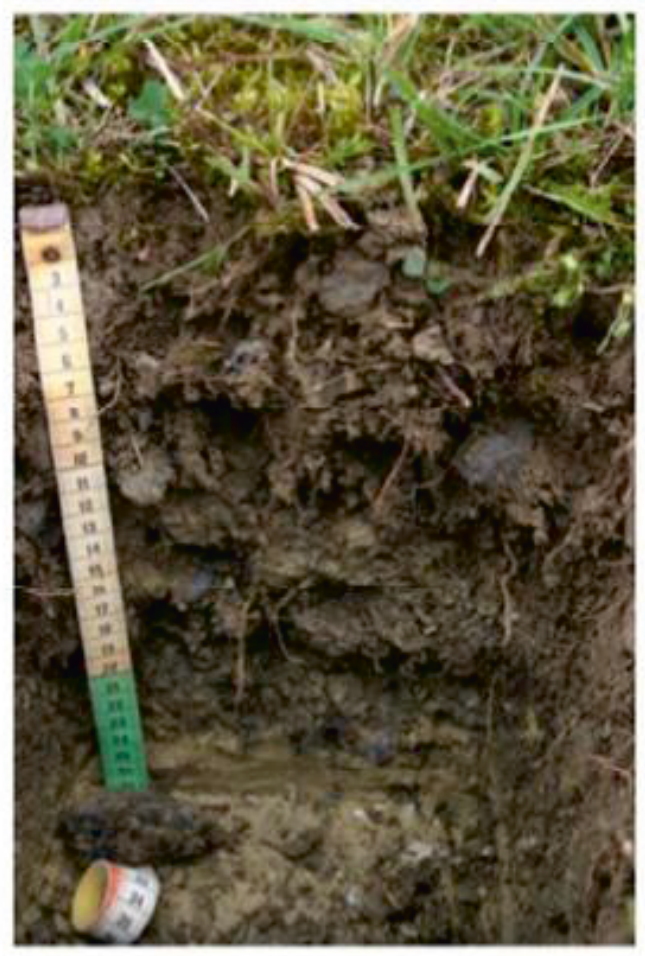

b)

Figure 3 Soil profiles of the unsealed road section: a) at a wet site in the bed of a brook; b) at a dry and gravelly site. The soil is a Densic Regosol with artificially compacted sandy loam.

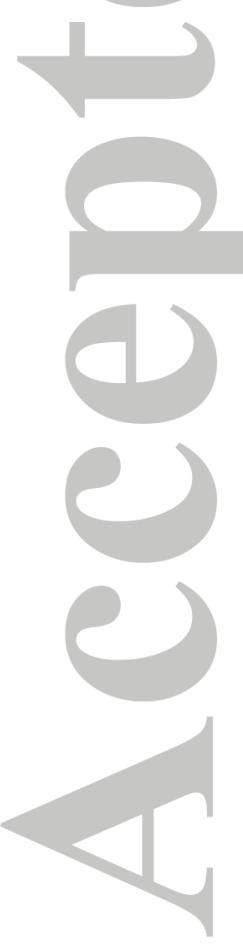

